OPEN ACCESS

Edited by:

Mamudu Abunga Akudugu, University for Development

Studies, Ghana

Reviewed by:

Cidonea Deponti,

Universidade de Santa Cruz do

Sul, Brazil

Mark Tilzey,

Coventry University, United Kingdom

*Correspondence:

Graciella Corciol

graciellacorcioli@ufg.br

Specialty section:

This article was submitted to Land, Livelihoods and Food Security, a section of the journal

Frontiers in Sustainable Food Systems

Received: 17 October 2021 Accepted: 06 December 2021

Published: 13 January 2022

Citation:

Corcioli G, Medina GdS and Arrais CA (2022) Missing the Target: Brazil's

Agricultural Policy Indirectly Subsidizes Foreign Investments to the Detriment of Smallholder Farmers and

Local Agribusiness.

Front. Sustain. Food Syst. 5:796845 doi: 10.3389/fsufs. 2021.796845

\section{Missing the Target: Brazil's Agricultural Policy Indirectly Subsidizes Foreign Investments to the Detriment of Smallholder Farmers and Local Agribusiness}

\author{
Graciella Corcioli ${ }^{1 *}$, Gabriel da Silva Medina ${ }^{2}$ and Cristiano Alencar Arrais ${ }^{3}$ \\ ${ }^{1}$ Faculty of Agronomy - Rural Development Sector, Universidade Federal de Goiás, Goiânia, Brazil, ${ }^{2}$ Faculty of Agronomy \\ and Veterinary Medicine, Universidade de Brasilia, Brasilia, Brazil, ${ }^{3}$ Faculty of History, Universidade Federal de Goiás, \\ Goiânia, Brazil
}

Currently there is controversy about the effect of direct foreign investment in the Brazilian agricultural sector, mainly due to the impact it has on small farmers, land use, the environment, and food security. In this context, Brazil finds itself in an even more delicate situation, since in order to remain a bulwark of the economy, Brazilian agribusiness depends heavily on public policies that directly impact its treasury. This suggests there is an indirect transfer of public resources to transnational companies involved in agribusiness production chains. This paper assesses the allocation of agricultural credits in Brazil and the market share held by Brazilian groups, vis-à-vis multinational corporations in the agribusiness supply chains. The study was carried out analyzing the three largest supply chains established in the country: soybean, corn, and cattle. Results reveal that $75 \%$ of the operating credit (crédito de custeio), which represents $60 \%$ of the total government credit in Brazil, goes directly to soybean, corn, and cattle farmers. Most of this subsidized credit budget goes to the soybean farmers, which are mostly encompassed by large farmers. Results also reveal that $76.1 \%$ of the soybean supply chain in Brazil is controlled by foreign multinational corporations. These findings suggest that resources invested in large farmers that take part in supply chains controlled by multinational foreign groups end up indirectly financing foreign companies to the detriment of local smallholder farmers and domestic agribusiness. This highlights the need for restructuring Brazilian agricultural policy in favor of family farmers and domestic agribusiness.

Keywords: foreign direct investments, agro-industrial crop production, agricultural policy, domestic market share, agriculture supply chain

\section{INTRODUCTION}

The need to generate employment and income in developing nations attracts foreign investment that is often concentrated in the agricultural sector, mainly for the large-scale production of certain goods for export. Since the 1970s, Brazil has experienced this kind of growth in the rural environment which has attracted international companies, but which has also been fostered mainly 
by public policies of the Federal Government. Through this growth, Brazil has become one of the major agricultural producers in the world, as agribusiness has become the driving force of the national economy and economic growth. However, criticism of this developmental model has led to a debate around Brazilian agribusiness and its great influence.

Among the criticisms of the sector, the following stand out: (1) the large proportion of public resources channeled to the rural production of primary products for export; (2) the expansion of areas for production of these products (especially soy), often linked to land grabbing-which increases agrarian conflict and disrupts traditional productive dynamics and land use-expelling family farmers and compromising food and nutritional security; and (3) the increase of environmental degradation in these productive areas, highly dependent on chemicals and often deforested for integration into the production process. This dependence on public resources, the expansion of productive areas, and the leniency of enforcing environmental policies raise doubts about the true effective capacity that Brazilian agribusiness presents as a reliable economic sector.

In the last few decades, accompanied by the productive increase resulting from the Green Revolution, it has become commonplace to associate the economic agents linked to agribusiness as the champions of Brazilian economic development. Strong media campaigns along with robust numbers of commodity production have coincided with the formalization of a highly representative and influential political interest group, which has infiltrated both the Legislative and Executive branches.

In the current federal legislature (2018-2022), the so-called Agribusiness Parliamentary Front (FPA) is composed of 245 deputies and 39 senators, "totaling a block of 284 congressmen that corresponds to $47.8 \%$ of the National Congress, which is composed of 513 deputies and 81 senators" in total (de Carvalho and de Oliveira, 2021, p. 48). The significant number of congressmen linked to the agribusiness sector has been growing since the redemocratization process of the 1980s (Messenberg, 2002). The 2007-2011 legislature was composed of 116 PFA congressmen and the 2011-2015 legislature was composed of 160 PFA legislators (142 deputies and 18 senators), whose electoral campaigns were financed by companies or individuals directly linked to the candidates (23\% originated from individual donations and 39\% linked to companies). Much of this financing has come specifically from the manufacturing industry (including the processing industry), construction and commerce (76\% of the entire amount of resources allocated to the candidates' campaign, an approximate value of 46 million reals) (de Camargo, 2009; Machado, 2013).

The Agribusiness Parliamentary Front also exerts strong influence in the appointment of the Minister of Agriculture, the presidency of the Bank of Brazil, and the advance of legislative reform projects directly linked to the political interests of the sector, such as PEC 215, the extinction of the MDA, the weakening of the powers of INCRA, the labor legislation, CONAMA, as observed in the impeachment process of former President Dilma Roussef. Moreover, in the process of the elaboration and implementation of the Brazilian agrarian and agricultural policy over the last few decades, the leaders of the agribusiness sector have had a leading role, especially in the Standing Committees of the House of Representatives. The Agriculture Commission, the Environment Commission, the Amazon Commission, the National Integration Commission, and the Regional Development Commission are dominated by this supra-partisan group (Castilho, 2012).

In this context, the Complementary Law No. 87 of September 13, 1996 (Kandir Law) deserves to be highlighted as it eliminated the collection of taxes that had been levied on the exportation of primary products, specifically for the rural producers of the main export crops, with a chain effect. Other demonstrations of the influence this sector has on policy is the constant renegotiation of debts in owner-occupier agriculture, the devaluation of the Real against the Dollar, and government subsidies for the fleet modernization of agricultural machinery (MODERFROTA) (Ribeiro Neto, 2018).

As a public policy, the Plano Safra has focused mainly on subsidized credit for rural producers, with most of the resources going to funding the large producers (de Moraes, 2014). The last Plano Safra had a forecast of R\$251 billion, of which R\$73.4 billion were for investment credit and R\$ 177 for costing and commercialization (MAPA, 2021). Most of this was allocated to large producers who received $\mathrm{R} \$ 50.9$ billion for investment and $\mathrm{R} \$ 127$ billion for funding (MAPA, 2019) ${ }^{1}$.

In practice, the operating cost credit is used as working capital by the rural producer to buy production supplies such as seeds, pesticides, fertilizers, medicines, and feed. The operating cost credit is made for each production cycle, with the payment being made at the end of the production. Investment credit, on the other hand, allows the purchase of agricultural machinery, implements, and matrices that are configured as longterm investments (Betarelli Junior et al., 2019). This credit is made by banks with private capital and requires government subsidy to reduce interest rates (equalization) with the use of public resources.

Advocates of the current Brazilian agricultural policy argue for the importance of maintaining credit given the importance of agribusiness for the Brazilian trade balance and for the benefit of rural producers, who would otherwise resort to financing from trading companies in the barter system or reserving resources for working capital (Xavier, 2021). The credit subsidized by the government is also a guarantee in the case of significant losses given the flexibility of renegotiating their debt with the State, which is more difficult in the private sector which requires mechanisms such as the guarantee of payment by the rural product bill ${ }^{2}$. Producer associations, particularly Aprosoja and

\footnotetext{
${ }^{1}$ Medium-sized producers were allocated $\mathrm{R} \$ 3.8$ billion for investment and $\mathrm{R} \$ 29.4$ billion for funding through the National Support Program for Medium Producers (Pronamp). Family farmers were allocated R $\$ 13.6$ billion for investment and R\$19.4 billion for funding through the National Program for the Strengthening of Family Agriculture (Pronaf) (MAPA, 2019).

${ }^{2}$ Given that agricultural policy resources are scarce, the public authorities understood the need for the participation of private investors to better develop the sector. In this context, Law 8,929/94 introduced the Rural Producer's Certificate (CPR), which enables the producer to make physical or financial settlement to his creditors. At the maturity determined by the title, the CPR holder may demand the product from the issuer, in the quantity and quality established.
} 
CNA, are advocates of subsidized credit for rural producers (CNA, 2018).

On the other hand, there has been a growing criticism of the current model of Brazilian agricultural policy, which for decades has prioritized subsidized credit (Medina, 2018; Junior and Goldfarb, 2021), differing from policies of others such as the United States and the European Union (Potter and Tilzey, 2007; Mcfadden and Hoppe, 2017; Prokopy et al., 2019). Studies also highlight the "supposed contribution" of agribusiness to the national economy, which disregards the rolling over of the sector's significant debts that have historically accumulated (Mendonça, 2015). Additionally, investigations reveal that credit has continually been allocated to the same producers and conventional production chains (soy, meat, milk), despite the increase in the volume of resources (Corcioli, 2019).

For Leite (2020), this model has had the participation of the Brazilian State, whether through indirect policies, such as those focused on infrastructure, foreign exchange, and tax incentives, or through direct policies such as rural credit. These criticisms reveal Brazilian agribusiness as a segment whose competitiveness is largely due to the high degree of benefits it has received over decades. These benefits include an agrarian policy that has colluded with land grabs (Nepomuceno et al., 2019), an environmental policy lenient on illegal deforestation in agricultural frontiers (de Mello-Thery, 2019), and tax waivers, such as those of the Kandir Law, which has made exports of primary products such as soybean tax exempt (da Silva and Gonçalves, 2019). Despite the numerous benefits, Brazilian agribusiness continues to demand the reduction of the "Brazil Cost" with public investments to improve the conditions for production flow and subsidized credit for rural producers from public resources.

The advent of studies in agribusiness accentuates an additional aspect to be considered: agricultural policy in the face of Brazilian participation in the production chains of established agribusiness in Brazil (Santos and Glass, 2018). These studies reveal the importance of analyzing the entire production chain (Koberg and Longoni, 2019), since the suppliers of the production inputs in Brazil have increasingly become foreign multinationals (Medina, 2021). In other words, contrary to what has been stated by the political interest groups linked to the rural sector as a justification for maintaining the current rural credit model, the wealth produced by Brazilian agribusiness is not economically equally distributed in Brazilian society. Especially wealth linked to the production of commodities, which has no redistributive characteristic for the country. In fact, this wealth seemingly disappears into the trade cycle and mostly into the hands of multinational corporations.

Thus, we defend the hypothesis that the current agricultural policy indirectly finances foreign corporations with public resources and funding without actually contributing to the development of domestic agribusiness. Recent studies have pointed to the fact that agricultural policy resources are transferred to a small number of transnational corporations that control the agricultural supply market in Brazil. This occurs mainly in the seeds and agrochemicals segments, but also, in the case of investment resources, directed to the purchase of agricultural machinery which is a sector chiefly controlled by multinationals (Wesz Junior and Grisa, 2017).

With economic liberalization in the 1990s, some commodity production chains with great international demand received large investments from multinational groups, including for the purchase of local companies, as is the case of the soybean production chain (Bassi et al., 2013; Costa and Santana, 2014). Other production chains have also received significant investments, but with greater participation of local investments, as is the case of the beef production chain, which is also characterized by a greater participation of family farmers (Meurer et al., 2015).

This paper seeks to evaluate the effectiveness of the current Brazilian agricultural policy in supporting the development of Brazilian agribusiness from the knowledge about the Brazilian participation in production chains. Specifically, it intends to:

- To survey the effective allocation of subsidized agricultural credit by the Brazilian State;

- Assess the participation of Brazilian groups in relation to foreign groups in the main production chains; and

- Discuss to what extent the use of public resources is directed to the interests of the country and the need for adjustments.

\section{Theoretical Framework}

Literature on foreign direct investment (FDI) by multinational enterprises has focused on outcomes for the host countries such as spillover effects, technology transfer, firm-level productivity, and performance of subsidiaries. These studies have concluded that subsidiary performance improves with the integration of a parent firm's technological and marketing knowledge resources and the co-presence of high technological and market relatedness (Paul and Feliciano-Cestero, 2020).

Empirical evidence has also shown that the effects of FDI are heterogeneous and conditional on factors such as the type of FDI, the economic sector of investment, and the absorptive capacity of the host economy principally (Colen et al., 2008; Economou, 2019). Proponents who believe that such investments in the agricultural sector is a panacea for a developing country's problems, argue that the investments will bring about economic and social benefits including employment creation, income and livelihood diversification strategies

However, the potential of FDI for the agricultural sector of developing countries, particularly agro-industrial production, is still a contested issue in terms of job creation and income generation. Research findings have revealed cases where FDI stimulated no economic growth in host countries (Carbonell and Werner, 2018). Skeptical perspectives contend that because the investments are channeled into large scale agro-industrial and biofuel crop production, the negative effects, such as the alienation of smallholder farmers from their lands and increases in food prices, far outweigh any positive impacts of the investments.

However, existing studies have only recently started exploring whether or not and to what degree have domestic entrepreneurs benefitted from the economic dynamics promoted by FDI, by establishing themselves in the marketplace while competing with 
multinational foreign enterprises (Thomé et al., 2017). In Brazil, it has been argued that the promotion of agribusiness has led to the development of agricultural supply chains dependent on foreign investments, but with the limited participation of domestic groups (Medina and Santos, 2017).

Liberal approaches may attract FDI to developing countries and in contrast, stronger governmental support may lead to the protection of local businesses that are not necessarily efficient. In Brazil, specifically since the 1990s, the neoliberal economic perspective has been promoted through relaxed economic regulation and privatization policies (Mueller and Mueller, 2016). With economic liberalization, the entry of international capital into the country has boosted agribusiness and created a more competitive environment for national groups (Saes and Silveira, 2014).

But long-run dynamic comparative advantages (Salerno, 2017) - that required the creation of improved technological capabilities - were disregarded (Di Meglio et al., 2018), leading to a reduced market share held by national groups in the industrial sectors of agribusiness made in Brazil (Medina, 2021). It is argued that structural change toward a more sophisticated industrial base is a sine qua non condition for an emerging economy to converge from developed ones. Therefore, it is necessary to create opportunities for national groups to increase their share in industrial sectors based on long-term policies in industry and technology (Nassif et al., 2017).

The current situation of a liberal and globalized business environment in Brazil results in the need for a clear assessment of the opportunities created by dynamic economic sectors, such as agribusiness, for domestic groups to thrive. A crucial challenge is the consolidation of companies with domestic capital throughout the supply chain of agribusiness in developing countries (Kano et al., 2020). Building on this background, a key academic issue that needs to be understood is to what degree have domestic entrepreneurs established themselves in the business and benefits from FDI, which has promoted dynamic economic sectors such as agribusiness in Brazil in the last few decades.

\section{METHODOLOGY}

The analysis of the effective allocation of Brazilian rural credit was based on data published by the Central Bank of Brazil obtained from the Rural Credit Data Matrix ${ }^{3}$. The analysis considers the resources applied to the soy production chain and to beef and dairy farming from 2013 to 2021, since data on rural credit first became part of the matrix in 2013. To demonstrate the stratification of the applied resources, the study considered the credit released in the transactions of investment, operations, and commercialization, with an emphasis on the National Support Program for Medium Producers (Pronamp) and the National Program for the Strengthening of Family Agriculture (Pronaf).

More focus was given to the operating cost credit since the investment data did not allow us to distinguish investment according to production chain. Also, an important part of the investment credit goes toward machinery that is used in different

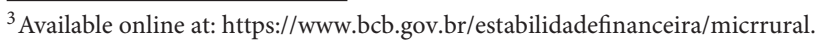

production chains (soy, sugar cane, milk, meat, etc.). The data analyzed was customized to consider five categories of the Rural Credit Matrix, and for the credit total we used the Quantity and Value of Contracts by Region, State and Gender filter ${ }^{4}$.

To estimate the participation of domestic groups, the first step of this work was to identify the main segments of the soy, corn, and beef and dairy cattle production chain in Brazil. As defined by the production sector itself, these segments include: seeds, fertilizers/animal nutrition, agrochemicals/animal health, machinery, production, and processing and commercialization (Embrapa, 2019). Next, the main companies operating in each productive segment were identified, which was done based on document research of institutional materials from the sector associations and the companies themselves ${ }^{5}$.

From the information gathered, we estimated the participation (market share) of the companies operating in each segment analyzed. First, we quantified the total sales in the country for each input in each segment of the four supply chains (e.g., 5,580 soybean harvesters sold in Brazil in 2019). We then identified the major international and domestic companies operating in each segment (e.g., CNH, John Deere, and AGCO in the case of soybean harvesters), and their total sales (e.g., 2,903 soybean harvesters by $\mathrm{CNH}, 2,269$ by John Deere, and 408 by AGCO). In all cases, the sources have been cited throughout the paper.

In addition to estimating the market share in the main productive segments, the shareholding composition of the companies was surveyed as a way to identify the participation of domestic groups in relation to multinationals. To estimate the total market share of domestic groups $(\mathrm{P})$ in each segment of the production chain, the market shares of all companies with Brazilian capital were summed $\left(\sum \mathrm{ni}=1 \mathrm{Br}\right)$. The domestic participation in the production chain (PD) resulted from the weighted sum of the participation of business groups with Brazilian capital in each of the six segments analyzed (from seeds to marketing), according to Equation 1 below. The results are presented in Figure 4 of this study:

$$
\begin{aligned}
P D & =(P 1+P 2+P 3+P 4+P 5+P 6) / 6 \\
\text { where } P & =\sum n i=1 B r
\end{aligned}
$$

${ }^{4}$ For soybean cultivation two filters were used: (1) Quantity and Value of Agricultural Custody Contracts by Product, Segment and (2) FI and Quantity and Value of Agricultural Commercialization Contracts by Product, Segment and FI. For bovine farming, we used the filters (1) Quantity and Value of Livestock Financing Contracts by Product, Segment and FI and (2) Quantity and Value of Livestock Marketing Contracts by Product, Segment and FI. This data was computed in full, in order to establish the values and percentages applied in each modality and/or activity.

${ }^{5}$ In Brazil, producer associations organized by productive segments estimate the participation of their members in the market and disclose this information in statistical yearbooks, often available on their websites. Examples are the Brazilian Association of Milk Producers (Leite Brasil-http://www.leitebrasil.org.br/), the National Union of Animal Feed Industry (Sindirações-https://sindiracoes.org. $\mathrm{br} /$ ) and other associations mentioned throughout the study. With the list of companies operating in each productive segment, a survey was conducted of the institutional materials available on the website of each of the identified companies. 


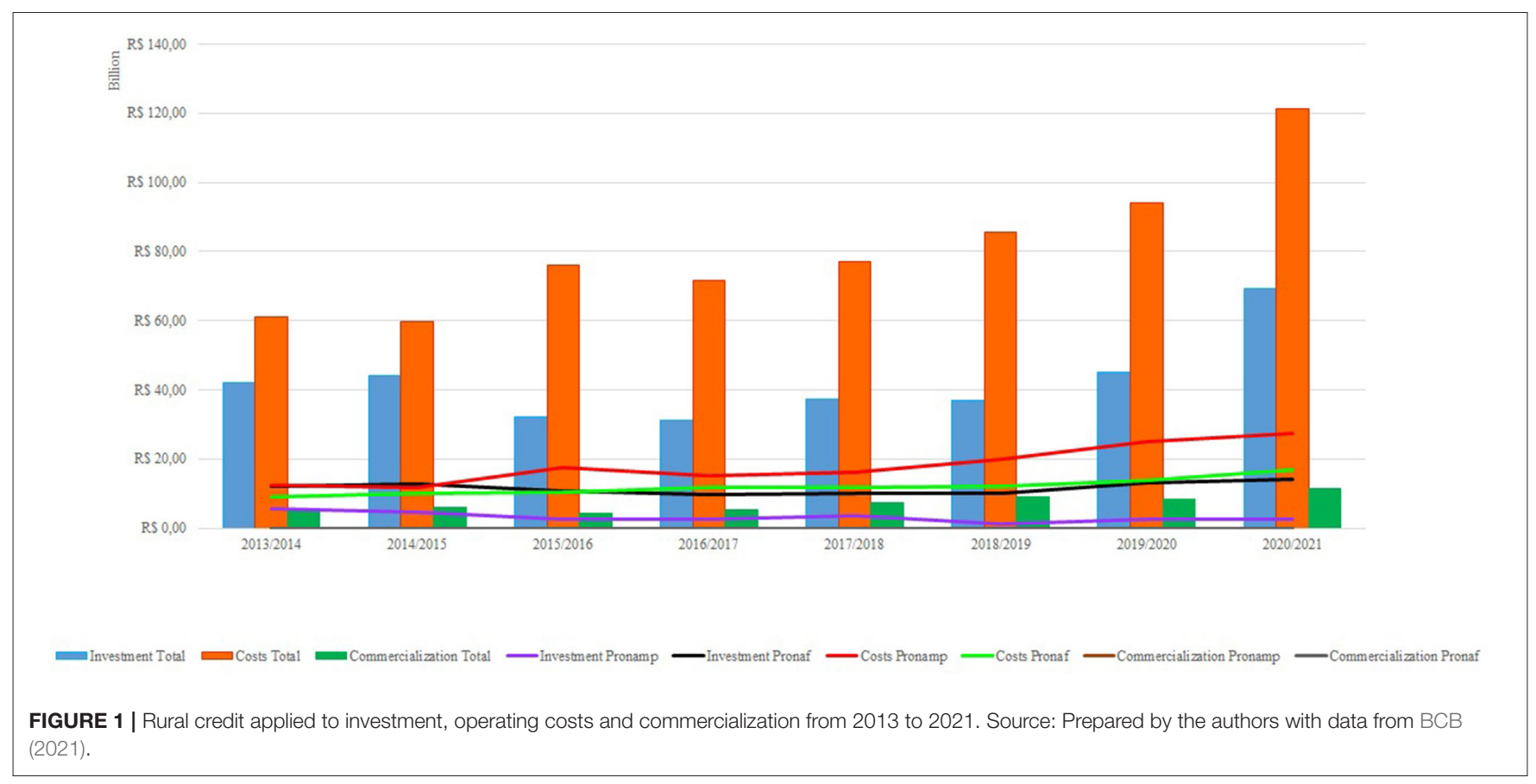

Where $P D$ is the Domestic Participation in the production chain; $P$ is the Domestic participation in each segment (from seeds to marketing); and $\sum n i=1 \mathrm{Br}$ is the sum of the domestic participation of each segment of the production chain.

\section{RESULTS}

\section{Credit Allocation}

Figure 1 shows the distribution of rural credit among the modalities of investment, operating costs and commercialization, with an emphasis on specific lines for medium-sized rural producers (Pronamp) and family farmers (Pronaf).

In Figure 1 it is possible to observe in all the years studied, that the resources applied to operating costs exceeded the other modalities, representing more than $60 \%$ of the total amounts applied in the last 5 years. Also, a greater allocation of resources for large producers can be seen, since the resources applied by medium-sized producers never exceeded $19 \%$ of the total amount, while family farmers applied $18 \%$ of the total volume of rural credit resources on average. The commercialization modality was not used by medium-sized producers and family farmers in the years studied.

The operating modality represented $62 \%$ of the volume of rural credit resources applied to Brazilian agriculture and cattle raising from 2013 to 2021 on average. An average of 33\% of this total, which is currently around R $\$ 120$ billion, was applied only to soybean crops. Of this $33 \%$ allocated to soybean, $6 \%$ was applied to medium and $4 \%$ to family farmers, respectively, while 23\% was applied to large rural producers (Figure 2).

Corn ranks fifth in Brazilian exports and when it comes to grains, corn is second only to soybean, which is first in products exported by the country. Figure 3 shows the amounts (in Brazilian Reals) and the percentages of rural credit applied to the operating costs of corn grain between 2013 and 2021. In Figure 3 we can see that corn used an average of $12 \%$ of the total volume applied to operations. When adding soy to this, one can see that the two crops together make up $45 \%$ of the total value of agricultural and livestock funding.

Figure 4 represents beef and dairy farming in Brazil. One can see that this activity received $29 \%$ on average, of the total value of agricultural and livestock costs from 2013 to 2020. When we add the amounts applied to the operating costs of soy and corn, the total amount represented by these three segments is close to $75 \%$ of the total agricultural and livestock operating costs applied during this period.

Medium-sized producers and family farmers utilized 8 and 5\% on average, respectively, while the large rural producers utilized on average, $16 \%$ of the operating cost amounts for beef and dairy cattle farming (Figure 4).

Comparing the resources applied to the funding of soy, corn and cattle, it is possible to see that cattle has a greater participation of medium-sized producers and family farmers. This finding is important given the number of medium-sized producers and family farms in the countryside, which together represented $99.87 \%$ of Brazilian agricultural and livestock farms in 2017 (IBGE, 2019).

According to the 2017 Agricultural Census, there were 237,118 establishments that grew soybeans, which represent $5 \%$ of the total number of agricultural establishments in the country. Of these, $95 \%$ are medium-sized producers or family farms. However, when it comes to comparing harvested area, quantity produced, and value of production, medium-sized producers and family farmers accounted for only 9 and $23 \%$, respectively.

The 2017 Agricultural Census also shows that 1.6 million establishments cultivate corn, of which $81.1 \%$ are family farms, $18.6 \%$ are medium-sized farms, and $0.3 \%$ are large rural 


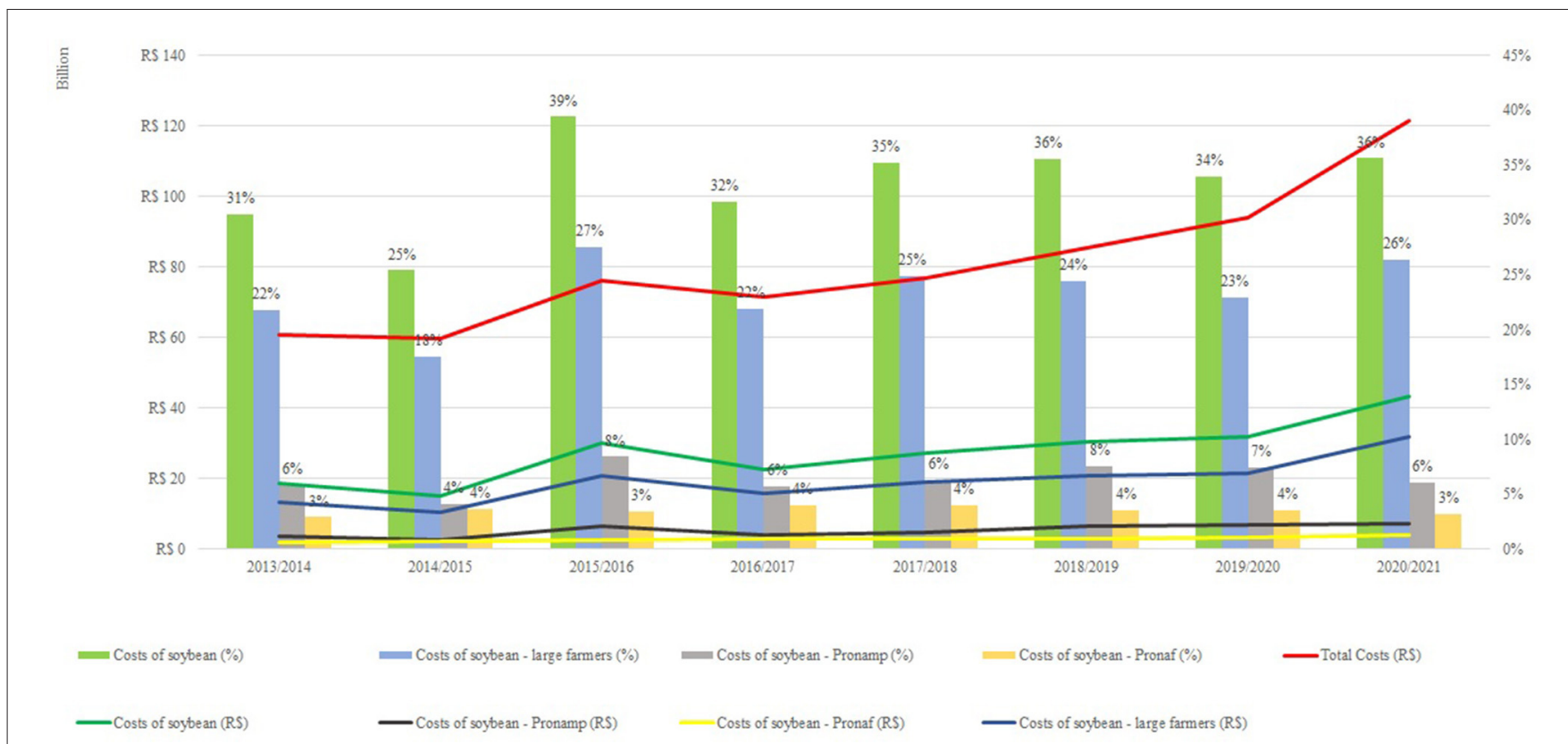

FIGURE 2 | Amounts and percentage of rural credit applied to total operating costs, total operating costs of soybean, and operating costs applied to soybean crops of large, medium and family farmers from 2013 to 2021. Source: Prepared by the authors with data from BCB (2021).

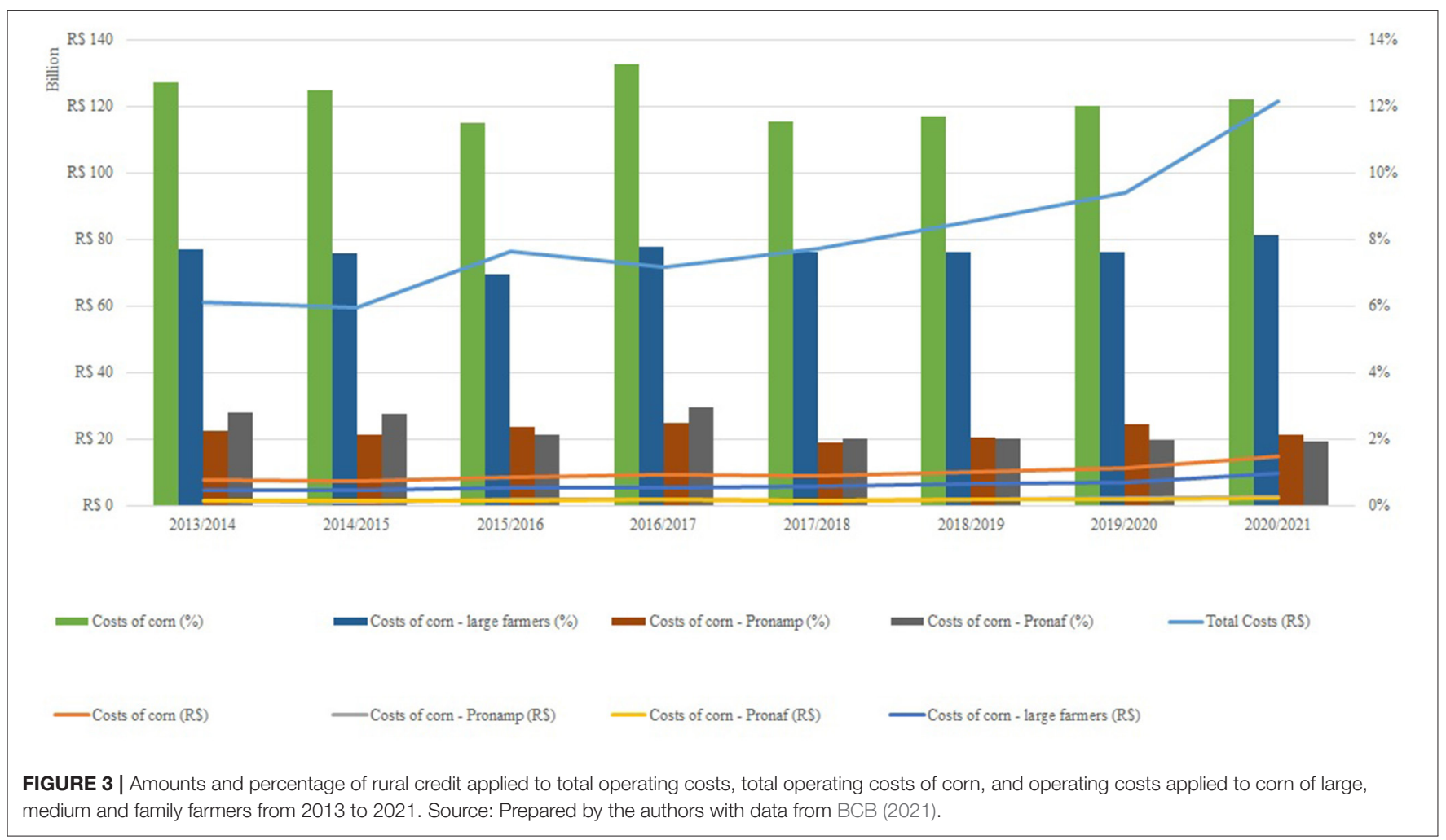

producers. As with soybean, when it comes to the value of production, large rural producers make up $62.5 \%$ of the total, while medium-sized rural producers make up $20.8 \%$, and family farms only $16.7 \%$.
Utilizing the data from the BCB and the 2017 Agricultural and Livestock Census, it can be stated that between 2013 and 2021 , only $5 \%$ of the total Brazilian agricultural and livestock establishments used $20 \%$ of the rural credit exclusively for 


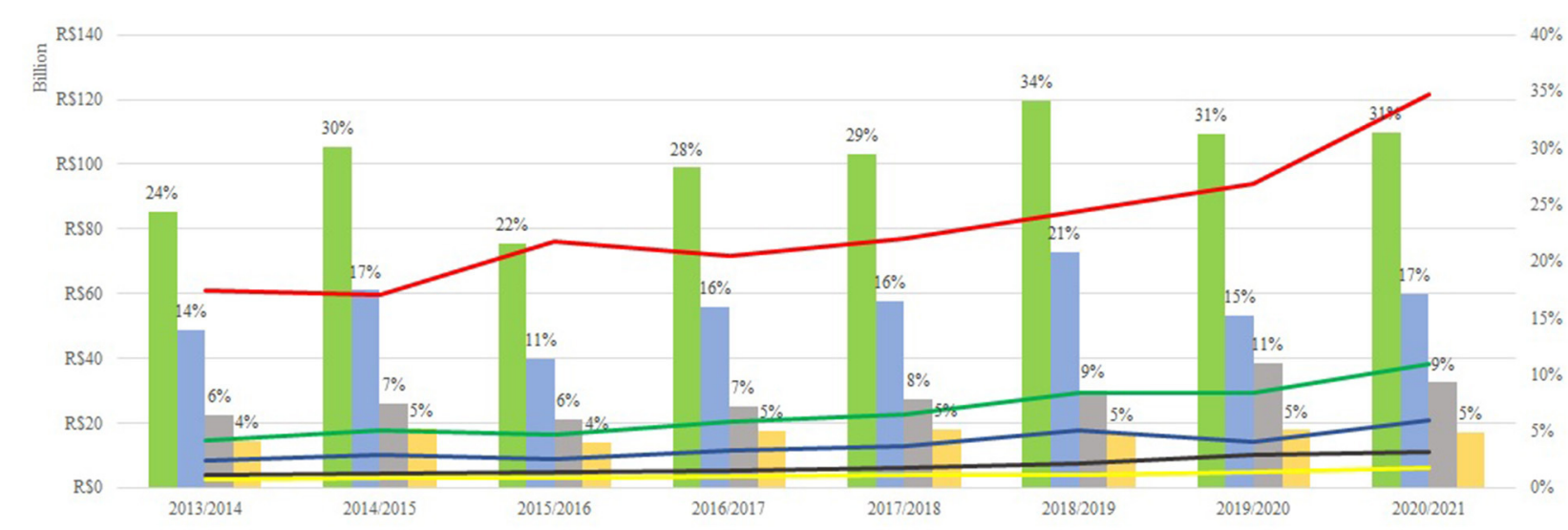

Costs of cattle (\%)

Costs of cattle - large farmers $(\%)$

Costs of cattle - Pronamp (\%)

Costs of cattle - Pronaf (\%)

- Total Costs (RS)

- Costs of cattle (RS)

- Costs of cattle - Pronamp (RS)

Costs of cattle - Pronaf (RS)

- Costs of cattle - large farmers (RS)

FIGURE 4 | Amount and percentage of rural credit applied to total operating costs, total operating costs of cattle, and operating costs applied to cattle of large, medium and family farmers from 2013 to 2021. Source: Prepared by the authors with data from BCB (2021).

soybean operating costs. Therefore, all of other modalities of credit (investment, commercialization and industrialization), other activities, and the remaining $95 \%$ of establishments, were left with $80 \%$ of the rural credit resources.

This is even more surprising when we see that only $4.15 \%$ of the establishments that cultivate soy in Brazil are large producers, and yet these producers used $14.8 \%$ of all rural credit resources from 2013 to 2021 for only soybean operations.

Corn has also highly concentrated public financial resources, as it consumed $7 \%$ of the total value of rural credit only in operational costs. Corn is a crop that is widely distributed among agricultural establishments in Brazil, since it is part of the Brazilian diet and is widely used for animal feed. However, the rural credit applied to the operating costs of the activity financed is mainly for the large rural producers, since only $0.3 \%$ of the rural establishments that produced corn used $70 \%$ of the available credit applied. These establishments belong to large rural producers.

In the case of cattle farming, the 2017 Agricultural and Livestock Census data indicates that there are 2,522,487 establishments engaged in this activity. These establishments represent $50 \%$ of the farms in Brazil and are all considered medium-sized producers and family farms (IBGE, 2019).

\section{Brazilian Participation Seeds}

In Brazil, 91.8\% of soybean seeds grown are GMO (transgenic) and the Brazilian GMO seed market is dominated by foreign corporations, specifically, Germany's Bayer, which holds a $90 \%$ market share (Soendergaard, 2018). Two-thirds of the profit from the final soybean seed price stays with the multinational licensor, while the remaining $35 \%$ goes to seed producers, since they pay royalties for the use of patented GMOs (Marin and Stubrin, 2015). In the soybean seed production segment, Brazilian companies hold $25 \%$ of the market share (Medina, 2021). Thus, in the seed segment, domestic capital is equivalent to only $8.7 \%$ (35\% of the profits with $25 \%$ of the market).

The Brazilian pasture seed market for cattle is fragmented and has a large share of domestic groups. Matsuda, a privately held Brazilian company, is a major player in this segment. Cultivars which are mostly selected based on natural variability and launched by the Brazilian Agricultural Research Corporation (Embrapa), in partnership with private companies, account for more than $70 \%$ of the Brazilian forage seed market (Embrapa, 2019). Recently, some multinationals have also started to enter the market, such as Barenbrug do Brasil, a subsidiary of the Royal Barenbrug Group based in the Netherlands, which started Brazilian operations in 2012. Thus, domestic groups are estimated to account for $95 \%$ of the pasture seed market in Brazil (Medina, 2020).

\section{Fertilizers and Nutrition}

Two types of companies operate in the fertilizer chain used in soybean planting: those that produce raw material and those that use the raw material to manufacture specific fertilizers. Since soy cultivation does not demand nitrogen fertilizer application, the main inputs are the macronutrients of phosphorus (44\% imported) and potassium (95\% imported) (Anda, 2020). The Brazilian multinational Vale was the largest producer of phosphorus and the only producer of potassium in Brazil. The production of these two inputs, however, is now controlled by the multinational Mosaic, and the overall share of domestic groups has fallen to $<9 \%$. As far as fertilizer 
TABLE 1 | Participation of domestic groups in the main segments of the soybean, corn and beef production chains, 2019.

\begin{tabular}{|c|c|c|c|c|c|c|}
\hline Segments & \multicolumn{2}{|r|}{ Soy } & \multicolumn{2}{|r|}{ Corn } & \multicolumn{2}{|r|}{ Livestock (Meat and Milk) } \\
\hline $\begin{array}{l}\text { Fertilizers/animal } \\
\text { nutrition }\end{array}$ & 19.2 & $\begin{array}{l}\text { Fertilizer } \\
\text { Production: } \\
\text { Phosphorous (56\% domestic) } \\
\text { - Mosaic: } 53 \% \\
\text { - Anglo American: } 12 \% \\
\text { - Other (50\%): } 35 \% \\
\text { Potassium (5\% domestic) } \\
\text { - Mosaic: } 100 \% \\
\text { Subtotal: } 8.7 \% \text {-median P } \\
\text { (17.5\%) and K (0\%) } \\
\text { Fabrication: } \\
\text { - Yara: } 25 \% \\
\text { - Mosaic: } 20 \% \\
\text { - Other: } 55 \% \\
\text { Total: } 19.2 \% \text { - [production (8.7\%) } \\
\text { and fabrication (29.8\%)] }\end{array}$ & 4.2 & $\begin{array}{l}\text { Fertilizer production } \\
\text { Multinational: } 94.1 \% \\
\text { - Nutrien: } 14.7 \% \\
\text { - Mosaic: } 36.8 \% \\
\text { - Yara: } 42.6 \% \\
\text { Domestic: } \\
\text { - Cibra: } 1.8 \% \\
\text { - Unigel: } 2.4 \%\end{array}$ & 70.7 & $\begin{array}{l}\text { Nutrition } \\
\text { Multinational: } \\
\text { - Nutron (Cargill): 10\% } \\
\text { - Tortuga (DSM): 10\% } \\
\text { - Phibro: 3.2\% } \\
\text { - Neovia (ADM): 3.1\% } \\
\text { - Agroceres: 2\% 1\% } \\
\text { - Other: } \quad \text { Domestic: 70.7\% } \\
\text { - Premix } \\
\text { - Algomix } \\
\text { - Minerphós } \\
\text { - Comigo } \\
\text { - Real H }\end{array}$ \\
\hline $\begin{array}{l}\text { Agrochemicals/ } \\
\text { animal health }\end{array}$ & 5.8 & $\begin{array}{l}\text { Agrochemicals } \\
\text { Multinational: } \\
\text { - Syngenta (ChemChina): } 18.6 \% \\
\text { - Bayer: } 15.7 \% \\
\text { - Basf: } 9.2 \% \\
\text { - UPL: } 8.9 \% \\
\text { - Outras: } 41.8 \% \\
\text { Domestic: } \\
\text { - Nortox: } 2.7 \% \\
\text { - Ourofino: } 2.1 \% \\
\text { - Other: } 1 \%\end{array}$ & 1.1 & $\begin{array}{l}\text { Agrochemicals } \\
\text { Multinational: } \\
\text { - Basf: } 18.2 \% \\
\text { - Corteva: } 12.7 \% \\
\text { - Adama: } 5.9 \% \\
\text { - UPL: } 8.8 \% \\
\text { - Syngenta: } 21.5 \% \\
\text { - Bayer: } 22.7 \% \\
\text { - FMC: } 9.0 \% \\
\text { Domestic: } \\
\text { - Ihara: } 1.1 \%\end{array}$ & 15.3 & $\begin{array}{l}\text { Animal health } \\
\text { Multinational: } \\
\text { - MSD: } 22.3 \% \\
\text { - Zoetis: } 22.1 \% \\
\text { - Boehringer: } 21.8 \% \\
\text { - Elanco (Bayer): } 13.8 \% \\
\text { - Other: } \quad 3 \% \\
\text { Domestic: } \\
\text { - Ourofino (83\% BR): } 9.6 \% \\
\text { - Other: } 7.4 \%\end{array}$ \\
\hline $\begin{array}{l}\text { Machines/ } \\
\text { equipment }\end{array}$ & 0.2 & $\begin{array}{l}\text { Tractors } \\
\text { - John Deere: } 36.7 \% \\
\text { - AGCO: } 30.4 \% \\
\text { - CNH: } 32.5 \% \\
\text { - Agrale (domestic): } 0.4 \% \\
\text { Harvesters } \\
\text { John Deere: } 40.7 \% \\
\text { Massey Ferguson and Valtra } \\
\text { (AGCO): } 7.3 \% \\
\text { Case and New Holland (CNH): } \\
\text { 52.0\% } \\
\text { Total: } 0.2 \%(0.4 \% \text { and } 0 \%)\end{array}$ & 0.2 & $\begin{array}{l}\text { Machines and tools } \\
\text { Multinational: } \\
\text { - CNH: } 35.2 \% \\
\text { - Deere and Co: } 51.4 \% \\
\text { - AGCO: } 13.2 \% \\
\quad \text { Domestic: } \\
\text { - Stara: } 0.2 \%\end{array}$ & 52.5 & $\begin{array}{l}\text { Milking tanks multinationals: } 95 \% \\
\text { - DeLaval } \\
\text { - GEA } \\
\text { Domestic: } 5 \% \\
\text { - Reafrio } \\
\text { - Haramaq } \\
\text { Animal Husbandry } \\
\text { Domestic: } 100 \%\end{array}$ \\
\hline $\begin{array}{l}\text { Processing/ } \\
\text { commercialization }\end{array}$ & 16.1 & $\begin{array}{l}\text { Crushers and tradings } \\
\text { - Cargill: } 11.4 \% \\
\text { - Bunge: } 9.4 \% \\
\text { - ADM: } 7.8 \% \\
\text { - Dreyfus: } 7.5 \% \\
\text { - Cofco: } 3.8 \% \\
\text { - Other: } 43.8 \% \\
\text { Domestic: } \\
\text { - Amaggi: } 6.6 \% \\
\text { - Coamo: } 2.3 \%\end{array}$ & 40.1 & $\begin{array}{l}\text { Commercialization } \\
\text { Multinational: } \\
\text { - Cargill: } 50.8 \% \\
\text { - ADM: } 28.6 \% \\
\text { - Bunge: } 18.4 \% \\
\text { Domestic: } \\
\text { - Amaggi: } 2.2 \% \\
\text { Feed Processing } \\
\text { Multinational: } 41 \% \\
\text { - Cargill: } 8.9 \%\end{array}$ & 73.8 & $\begin{array}{l}\text { Dairy Plants: } 71.9 \% \\
\text { - Italac: } 6.1 \% \\
\text { - Piracanjuba: } 5.7 \% \\
\text { - Unium: } 4.7 \% \\
\text { - Other: } \quad 55.4 \% \\
\text { Meat Packing Plants: } 75.7 \% \\
\text { - JBS (75\% BR): } 38.3 \% \\
\text { - Marfrig (85\% BR): } 16.5 \% \\
\text { - Minerva Brasil (46.8\% BR): } 27.6 \% \\
\text { - Other: } 13.3 \%\end{array}$ \\
\hline
\end{tabular}


into an independent company. Domestic groups control 15.3\% of the market, with an emphasis on the generic product segment, which Ourofino Saúde Animal-a publicly traded company-has an important share of Sindan (2019).

\section{Production}

More than $93 \%$ of the 57.2 million hectares used for grain cultivation in Brazil belong to Brazilian farmers. However, this sector has been undergoing major structural changes as large domestic corporations and even some foreign multinational groups have begun leasing (e.g., Los Grobo) and even buying land (e.g., Agrinvest).

In 2017, Brazil had 5,073,324 rural households and 1,176,295 farms producing 30.1 billion liters of cow milk (IBGE, 2019). In addition, 971 million liters of milk are imported per year, which is a volume equivalent to $3.2 \%$ of national production. This means that $96.8 \%$ of the milk consumed in the country is produced domestically. Similarly, beef cattle farming is a sector traditionally controlled by Brazilian family farms (Magro et al., 2019).

\section{Machines and Equipment}

The soybean market for heavy machinery is controlled by a global oligopoly led by the international groups: John Deere, $\mathrm{CNH}$ (owner of the brands Case and New Holland) and AGCO (owner of the brands Massey Ferguson and Valtra). These three groups combined control $99.6 \%$ of tractor sales and $100 \%$ of harvester sales in Brazil (Anfavea, 2020). Agrale, the only company with national capital in the sector, produces small-sized tractors with limited applications for soybean cultivation. There is a larger but undefined market share of domestic companies of agricultural implements, such as plows and cultivators. For corn, there is only national representation by Stara, which occupies a market share of $0.2 \%$ (Corcioli et al., 2021).

The multinationals DeLaval and GEA lead the market for machines and equipment for milk production. While DeLaval excels in milking and animal comfort machinery, GEA dominates the construction of large industrial plants. Multinational groups like Weizur and Plurinox also control the cooling tank markets, in which Brazilian groups like Reafrio, Haramaq and Ordermilk have only a marginal share. The two main pieces of equipment most for beef cattle are the contention trunk (or breech) and the scale. No foreign investments were identified in these companies and the sector is controlled by a large number of domestic companies.

\section{Processing and Commercialization}

Large multinational trading companies such as ADM, Bunge, Cargill and Dreyfus (known as the ABCD Group) dominate the soybean processing and commercialization segments. Recently, China National Cereals, Oils and Foodstuffs Corporation (COFCO) acquired the Brazilian company Noble Agri (commercial). Domestic groups, including companies and cooperatives (for example, Coamo and Comigo), control 16.1\% of the processing and commercialization of soy produced in Brazil (Table 1).
In corn, commercialization figures as the segment that moves the most resources within the chain, representing the highest revenues among the five segments. Cargill, as leader of the segment, and the Brazilian company Amaggi, that in 2019 had revenues of US\$ 5 billion, highlight this group. In processing, Brazilian capital participates in $59 \%$ of the establishments that produce feed and corn alcohol in Brazil (Corcioli et al., 2021).

The largest producers of the formal Brazilian milk market are the multinationals Lactalis (from France) and Nestle (from Switzerland). However, most of the market is still under the control of regional companies and cooperatives. Domestic companies with the largest share include Goiasminas (of the Italac brand) and Laticínios Bela Vista (of the Piracanjuba brand), both from the state of Goiás (LeiteBrasil, 2019). The meatpacking segment in Brazil is concentrated in three large, publicly traded Brazilian companies: JBS, Marfrig, and Minerva. Despite the market concentration, there are 1,334 meatpacking plants registered with the federal inspection service (MAPA, 2020). For example, JBS is controlled by the Brazilian J\&F Investimentos S.A and its shareholder composition is divided into: its control group (J\&F Investimentos S.A. and Formosa) with a $39.8 \%$ share; its treasury with $2.3 \%$; BNDESPar with $21.3 \%$; and the minority shareholders with $36.6 \%$ (JBS, 2020).

\section{Proportional Total}

The control by foreign multinationals can be observed in the soybean, corn, and cattle production chains as a whole. The soybean chain has only $23.9 \%$ proportional participation of domestic groups, while $76.1 \%$ is controlled by foreign multinationals. In the more capital intensive segments (excluding field production), domestic participation was estimated at only $8.4 \%$, with the following distribution: $1.5 \%$ in seeds, $3.2 \%$ in fertilizers, $1.0 \%$ in agrochemicals, $0.04 \%$ in machinery, and $2.7 \%$ in commercialization (Figure 5).

The corn chain presents similar results to those found in the soybean chain. The proportional participation of domestic companies in the segments analyzed is around $24.3 \%$. This is highlighted by $16 \%$ domestic participation in the production segment and 7\% in processing/commercialization (Figure 5).

In comparison, the proportional participation of Brazilian groups was estimated at $67.5 \%$ while the participation of foreign groups at $32.5 \%$ in the production chain of cattle (milk and beef). In the more capital intensive segments (excluding field production), the domestic participation was estimated at $51.3 \%$, with the following distribution: $15.8 \%$ in seeds, $11.8 \%$ in animal nutrition, $2.6 \%$ in animal health, $8.8 \%$ in machinery and $12.3 \%$ in processing/commercialization.

\section{DISCUSSION}

In Brazil, the context caused by the Methuen Treaty of "cloth and wine" of 1703, which consolidated the privilege of British trade in the territories controlled by Portugal, is well-known. It aggravated the transfer of wealth of the Lusitanian Empire to England and the consequent structural deficit of the trade balance, compensated throughout the eighteenth century by the contribution of a fifth of the Brazilian gold production 


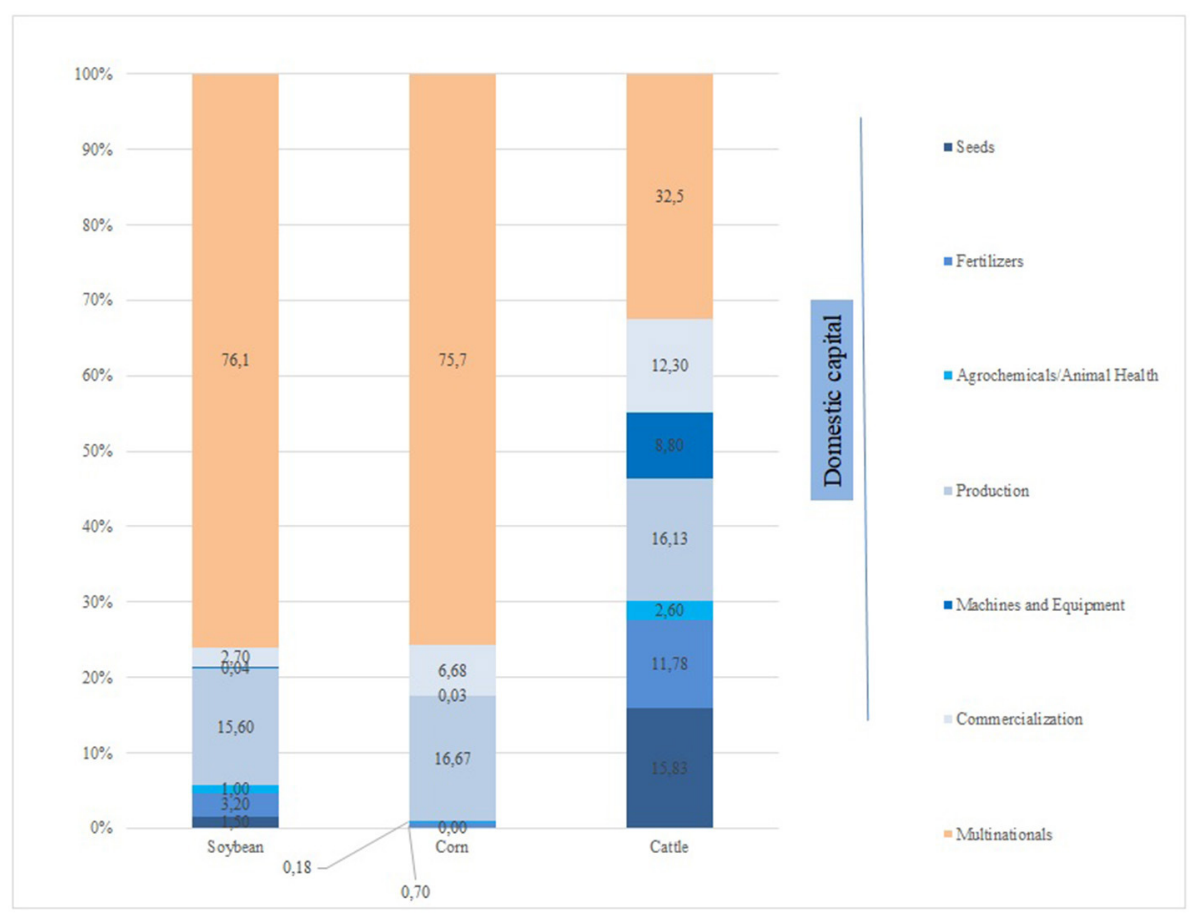

FIGURE 5 | Participation of domestic capital in the soybean, corn and cattle production chains in Brazil in 2019. Source: Prepared by the authors based on the weighted sum of the participations of domestic groups in the six segments analyzed according to Table 1.

(Falcon, 2005). In the mining regions, lacking supplies and with precarious productive balance, miners lived the illusion of instant prosperity, as gold was compulsorily transferred to the European colonial trade circuit (Arrais et al., 2019).

One can compare the context of the Methuen Treaty to the condition that Brazilian agribusiness finds itself in today. If, on the one hand, the process of wealth transfer from Brazilian agricultural production to foreign companies is a fact, the reverse process is questionable, since the agrochemical, machinery, and seed segments keep a large part of the profits generated by agribusiness. This maintains the illusion of wealth which is not socially divided, does not promote socioeconomic development, and benefits a restricted group of producers.

During the post-1945 process of re-democratization, the State consolidated itself as an agent for the protection of land interests, with significant political representation in the most conservative strata of the Brazilian Parliament, strongly mobilized through employers' unions and with a high rate of reappointment (Heiz, 2001; Mossenberg, 2002). After the military coup of 1964, this influence led to the occupation of the Brazilian West by extensive monocultures, especially corn and soy, and the public financing of the national agricultural and cattle production with the implementation of the National System of Rural Credit in 1965, a State Policy. This process culminated with the occupation of vast areas of the Midwest and North of Brazil.

The impact of the process of incorporation of large areas, previously occupied by native vegetation and traditional productive models or timidly linked to large export cultures was felt in a significant way. In the 1970s, Regional Development Programs were developed specifically for the incorporation of areas in southern Mato Grosso, northern Minas Gerais and southern Goiás to a type of high productivity agriculture to the detriment of subsistence crops and the consequent worsening of the economic dependence rates of rural workers (da Silva, 1979; Moro, 2014). Since then, the expansion of monoculture areas has become a reality with a high impact on the biomes and populations of traditional farmers in the interior of Brazil. Large areas of the native Cerrado biome have been occupied by soybean cultivation. In the region known as MATOPIBA-a polygon that covers territories of four states $-40 \%$ of this region's native vegetation area was lost. In the Amazon region, almost $30 \%$ of deforestation occurred due to the expansion of soybean cultivation by 2006 (Medina and Santos, 2017).

Other criticisms have been levied on the approach of Brazilian agricultural policy that for decades has invested mainly in subsidized credit for rural producers (Medina, 2018). Consolidated criticisms deserve to be highlighted, such as the fact that the resources benefit a restricted number of producers (Corcioli, 2019) and often the credits are not fully repaid as producers roll over outstanding debts (Mendonça, 2015).

Maintaining the existing agricultural policies in Brazil, as in other large producing countries (Potter and Tilzey, 2007; Mcfadden and Hoppe, 2017; Prokopy et al., 2019), is due to lobbying by special interest groups representing rural producers, particularly the large producers (CNA, 2018). These special interest groups tend to exert great influence in the development 
of public policies aimed at the rural sector and in the appointment of key positions in the Ministry of Agriculture, which is responsible for agricultural policy.

The comparison between the political dynamics that involve the permanence of Brazilian rural elites based on their political strength and the demonstration of the allocation of resources from the agricultural policy elaborated by these rural elites from the perspective of agribusiness productive chains allows us to state that:

- Most of the resources of Brazilian agricultural policy go to operating credit and most of it is allocated to soybean operations, which involves a relatively small proportion of producers. Corn involves a large number of producers, however, the biggest slice of the resources are allocated to large rural properties. On the other hand, cattle is present in most farms, but receives a smaller share of the resources. It is worth mentioning that there are several other productive chains in the country with a large participation of producers and that do not receive significant investments from the agricultural policy;

- The operating credit is used by producers to acquire productive supplies such as seeds, pesticides and fertilizers. In the soybean and corn production chains, these inputs are supplied mainly by foreign corporations, although in other chains there is a greater participation of domestic companies, as is the case of cattle. Besides not prioritizing the majority of the establishments, the credit allocated for the planting of soy and corn still benefits multinational companies to the detriment of Brazilian companies that have a smaller participation in the soy and corn production chains.

These results allow us to conclude that resources invested to provide subsidized credit to rural producers that participate in production chains controlled by multinational groups end up indirectly financing foreign companies with resources from Brazilian taxes. Recent studies point out that the transfer of resources from Brazilian agricultural policy to multinationals that control the agricultural input market in Brazil occurs both in the case of operating resources and also in the case of investment resources directed to the purchase of agricultural machinery, a sector controlled by multinationals (Wesz Junior and Grisa, 2017). These results further corroborate the analyses of Leite (2020, p. 242) who states that part of the soy production and "its respective crushing became the object of control of foreign groups (Argentine, American, Chinese, etc.)."

Furthermore, these two findings allow us to affirm that there is a link between agricultural policy implemented by the Federal Government and the economic groups most strongly represented in the National Congress-Agribusiness Parliamentary Front (FPA). These groups essentially hold national agricultural policies hostage according to the specific interests of political actors that are, at the same time, dependent on the multinational companies that dominate the commerce of commodities and standardized agricultural implements and inputs. This means that the current model of agricultural policy does not meet the objectives in terms of contributing to national economic development-as the tax waiver serving a select group of producers reached 26 billion reals in $2017^{6}$, since $20 \%$ of all rural credit finances soybean operations in $5 \%$ of rural establishments.

This type of agricultural policy strategy, in the short term, is leading the country to productive specialization and increasing dependence between productive sectors-understood as intermediaries of the large agricultural input conglomeratesand the Federal Government. In the long run, this productive specialization encourages the process of reprimarization of the economy to the extent that, as observed, investment in the processing of exported raw materials is dominated by multinationals. This means that there is also a geometric loss of value added to national production.

The competitiveness of Brazilian agribusiness thus becomes questionable and illusory, since it is based on tax waivers, debt forgiveness, subsidized credit, and a set of financial commitments that depend on political alliances. While the agricultural credit implemented by the Brazilian government is transferred to sectors of the economy controlled by multinational companies, with modest impact on the development of the distinct segments of the productive chains, such as Brazilian mineral production, used to pay the deficits of the Portuguese trade balance with England.

In view of this fact, there is a need for a policy that invests in productive chains with the participation of family farmers and with greater domestic participation, including the consolidation of Brazilian groups throughout the productive chains. In chains where the consolidation of domestic groups is possible, such as cattle, besides investments in the primary sector (producers), it is necessary to build strategies to support domestic groups established throughout the supply chain.

This case study in Brazil reveals that the potential of FDI for the agricultural sector of developing countries which is still a contested issue, particularly for agro-industrial production. In Brazil, the promotion of agribusiness has led to the development of agricultural supply chains dependent on foreign investments, but with a limited participation of domestic groups (Medina and Santos, 2017). Existing studies however only recently started exploring whether and to what degree domestic entrepreneurs can benefit from the economic dynamics promoted by FDI by establishing themselves in the marketplace while competing with foreign multinational enterprises (Thomé et al., 2017).

A crucial challenge is the consolidation of companies with domestic capital throughout the supply chain of agribusiness done in developing countries (Kano et al., 2020). Structural change toward a more sophisticated industrial base is a sine qua non condition for an emerging economy to converge from developed ones (Nassif et al., 2017). Therefore, it is necessary to create opportunities for domestic groups to increase their share in industrial sectors based on long-term policies such as industrial and technological policies (Nassif et al., 2017). The current situation of a liberal and globalized business environment in which the country operates, results in the need for a clear assessment of the opportunities that can be promoted by

\footnotetext{
$\overline{{ }^{6} \text { Data Available online at: https://www.brasildefato.com.br/2018/06/14/renuncias- }}$ fiscais-que-favorecem-o-agronegocio-crescem-83-no-governo-temer/ (accessed October 4, 2021).
} 
agroindustrial policies in favor of both smallholder farmers and domestic agribusiness.

On the other hand, the Pronaf credit as the main agricultural policy for family farming ended up supporting better-off farmers, more developed regions and monocultures such as soybeans and corn (Schneider et al., 2021). Even in left-wing governments such as Lula and Roussef between 2002 and 2016, there was greater support to large farmers than to family farmers, with limited land reform (Bonanno and Cavalcanti, 2019). Certainly, between 2002 and 2016 there was an effort to grow support to family farmers mainly through the credit line Pronaf Mais Alimentos launched in 2008, which targeted food production to local markets and food sovereignty (Wesz Junior, 2010). The current Bolsonaro government emphasized the support to large farmers, commodities and global agribusiness (Corcioli, 2019).

Domestic companies maintain large market shares in supply chains of native species (açaí, baru, cocoa, rubber) and organic products (Medina and Cruz, 2021), whose production in its majority done by family farmers. Such supply chains have positive environmental and social externalities, which would place them as priority for agricultural policies should the government seek to promote sustainable rural development. However, these supply chains are peripheral to Brazilian agribusiness exports and agricultural policies, as shown by data on access to credit.

To promote supply chains with greater market shares by domestic companies could be the first step in the transition to sustainable production systems aiming to strengthen family farming and environmental responsibility. However, this change will only be possible with the rupture of the current agricultural financing model and the consequent change in political conditions (Tilzey, 2021). In this sense, transition to a genuinely green economy would require the radical redistribution of land to agroecologically-based smallholder production and the elimination of agro-industrially produced exports priority. However, such transformation is hindered by the ultraconservative political pact that defines Brazilian agricultural policy today. Without breaking this vicious cycle that privileges export monoculture and, consequently, multinational companies to the detriment of the vast majority of the population of family farmers and sustainability, Brazilian agricultural policy will continue to miss its target.

\section{CONCLUSION}

Operating credit represented an average of $62 \%$ of the volume of rural credit resources applied to Brazilian agriculture and cattle from 2013 to 2020. Of the total applied to operating costs, which is currently around $\mathrm{R} \$ 93$ billion, about 33\% was allocated to only soybean cultivation. Of this $33 \%$ allocated for soybean operations, $23 \%$ was destined for large producers, $6 \%$ for medium producers and $4 \%$ for family farmers.

The soybean production chain has only $23.9 \%$ participation of domestic groups, while $76.1 \%$ is controlled by foreign multinationals. In the input and processing segments (excluding field production), the domestic participation was estimated to be only $8.4 \%$, with the following distribution: $1.5 \%$ in seeds, $3.2 \%$ in agrochemicals, $0.04 \%$ in machinery, and $2.7 \%$ in commercialization.

Considering that $33 \%$ of the operating credit goes to soy, it is estimated that only $8.4 \%$ of these resources is used by rural producers to buy supplies from the domestic industry, while $91.6 \%$ is used in purchases of inputs supplied by foreign multinationals established in the country. Comparatively, the resources allocated to the beef production chain tend to support the domestic industry more, since $51.3 \%$ of the input suppliers are domestic, thus benefiting a larger number of producers.

These results reveal that subsidized credit resources invested in rural producers that participate in production chains controlled by multinational groups end up indirectly financing foreign companies, to the detriment of promoting national agribusiness. This process of transferring the wealth produced in Brazilian soil to multinational companies in the agrochemical, machinery, and seed segments has been firmly incentivized by the Federal Government and benefits a restricted group of rural producers with political influence. On the other hand, there is little commitment to public policies that encourage production chains with the possibility of consolidating or investing in domestic groups already established in the production chain. This study highlights the need for restructuring Brazilian agricultural and industrial policies in favor of family farmers and domestic agribusiness in order to benefit from foreign investments in the sector.

The elaboration of public policies focused on productive diversity, food and nutritional security, and environmental sustainability should favor national development. This would ensure the production and distribution of food in the longterm for several countries, the reproduction and maintenance of rural communities, and the mitigation of environmental impacts caused by agriculture. International investments would therefore promote direct benefits for Brazil and society as a whole.

\section{DATA AVAILABILITY STATEMENT}

Publicly available datasets were analyzed in this study. This data can be found here: https://www.bcb.gov.br/ estabilidadefinanceira/micrural; http://www.leitebrasil.org.br/; https://sindiracoes.org.br/; https://sidra.ibge.gov.br/pesquisa/ censo-agropecuario/censo-agropecuario-2017.

\section{AUTHOR CONTRIBUTIONS}

GC: formulation of overarching research goals and aims and management and coordination responsibility for the research activity planning and execution and quantitative data of domestic market share. GM: methodology design, quantitative data of foreign direct investment, and revision of the first draft of the manuscript. CA: qualitative data assessment of agricultural policy and political history and revision of the first draft of the manuscript. All authors contributed to the article and approved the submitted version. 


\section{REFERENCES}

Aenda (2020). Associação Brasileira dos Defensivos Genéricos (AENDA). Available online at: https://www.aenda.org.br/ (accessed December 20, 2020).

Anda (2020). Anuário Estatístico. ed. Associação Nacional para Difusão de Adubos. São Paulo, Brasil: Associação Nacional para Difusão de Adubos. Available online at: http://anda.org.br/arquivos/ (accessed March 13, 2021).

Anfavea (2020). 53 Anuário da Indústria Automobilística Brasileira, 1st Edn. São Paulo, Brasil: Associação Nacional dos Fabricantes de Veículos Automotores.

Arrais, C. A., Oliveira, E. C., and Lemes, F. L. (2019). O século XVIII em Goiás: a construção da Colônia. Goiânia: Cânone Editora.

Bassi, N. S. S., da Silva, C. L., and Santoyo, A. (2013). Inovação, Pesquisa e Desenvolvimento na Agroindústria Avícola Brasileira. Estudos Soc. Agric. $21,392-417$

BCB (2021). Banco Central do Brasil. Available online at: https://www.bcb.gov.br/ estabilidadefinanceira/micrrural (accessed August 20, 2021).

Betarelli Junior, A. A., Faria, W. R., and Albuquerque, D. P. (2019). Crédito Rural, Tipos de Financiamentos e Efeitos Econômicos: O Caso Dos Recursos Equalizáveis de Juros Para o Investimento e Custeio Agropecuário No Brasil (2012). Brasília: Planejamento e Políticas Públicas, n. 52, 1-29.

Bonanno, A., and Cavalcanti, J. S. B. (Ed.). (2019). State Capitalism Under Neoliberalism - The Case of Agriculture and Food in Brazil. London, UK: Lexignton Books.

Carbonell, J. B., and Werner, R. A. (2018). Does foreign direct investment generate economic growth? A new empirical approach applied to Spain. Econ. Geogr. 94, 425-456. doi: 10.1080/00130095.2017.1393312

Castilho, A. L. (2012). O partido da terra: como os políticos conquistaram o território brasileiro. São Paulo: Contexto.

CNA (2018). O Futuro é Agro 2018-2023. Brasília: Confederação Nacional da Agricultura.

Colen, L., Maertens, M., and Swinnen, J. (2008). Foreign Direct Investment as an Engine for Economic Growth and Human Development: A Review of the Arguments and Empirical Evidence. Leuven: Leuven Centre for Global Governance Studies.

Corcioli, G. (2019). Evolução Do Pronaf No Estado de Goiás: Tendência de Concentração de Investimentos Em Atividades Pecuárias Tradicionais. Bol. Goiano Geogr. 39, 1-21. doi: 10.5216/bgg.v39i0.56141

Corcioli, G., de Paula, H. T. A., Silveira, F. C., and Rosa, D. F. M. (2021). "Cadeia produtiva do milho," in eds G. da S. Medina, J. E. Cruz. Estudos em Agronegócio: participação brasileira nas cadeias produtivas. V. 5 (Goiânia: Kelps), 390p.

Costa, N. L., and Santana, A. C. (2014). Estudo Da Concentração de Mercado Ao Longo Da Cadeia Produtiva Da Soja No Brasil. Rev. Estudos Soc. 16, 111-135. doi: 10.19093/res.v16i32.1853

da Silva, J. G. (1979). Dois enfoques sobre a agricultura no Brasil. Encontros com a Civilização Brasileira. Rio de Janeiro: Civilização Brasileira, n. 10, 58-69.

da Silva, R. D., and Gonçalves, G. M. (2019). Exportações e o desenvolvimento regional: um balanço da Lei Kandir para o Rio de Janeiro, Paraná e Minas Gerais. Semestre Econ. 22, 179-204. doi: 10.22395/seec.v22 n50a9

de Camargo, O. J. R. (2009). Elite política brasileira e a renegociação das dívidas do crédito rural - o caso da bancada ruralista. (Dissertação de Mestrado). Programa de Pós-Graduação em Sociologia, UNICAMP.

de Carvalho, J. T., and de Oliveira, A. R. (2021). O agronegócio no Brasil: o discurso da fração de classe reinante. Revista NERA 24, 28-55. doi: 10.47946/rnera.v0i58.8082

de Mello-Thery, N. A. (2019). Perspectivas ambientais 2019: retrocessos na politica governamental. Confins: Revista Franco-Brasileira de Geografia, 501. Available online at: http://journals.openedition.org/confins/21182 (accessed May 26, 2021). doi: $10.4000 /$ confins. 21182

de Moraes, L. A. M. (2014). Brazil's agricultural policy developments. Rev. Polit. Agrícola 1, 55-64.

Di Meglio, G., Gallego, J., Maroto, A., and Savona, A. (2018). Services in developing economies: the deindustrialization debate in perspective. Dev. Change 49, 1495-1525. doi: 10.1111/dech.12444

Economou, F. (2019). Economic freedom and asymmetric crisis effects on FDI inflows: the case of four south european economies. Res Int Business Finance 49, 114-26. doi: 10.1016/j.ribaf.2019.02.011

Embrapa (2019). Anuário Leite 2019. Brasília: Embrapa Gado de Leite.
Falcon, F. J. C. (2005). O império luso-brasileiro e a questão da dependência inglesa - um estudo de caso: a política mercantilista durante a Época Pombalina e a sombra do Tratado de Methuen. Nova Econ. 15, 11-34.

Heiz, F. (2001). Elites rurais: representação profissional e política no Brasil, 19301960. Anuário IEHS, n. 16, 2001. Available onlibne at: http://anuarioiehs. unicen.edu.ar/Files/2001/006\%20-\%20Heinz,\%20Flavio\%20-\%20Elites \%20Rurais, \%20representacao\%20profesional.pdf (accessed October 6, 2021).

IBGE (2019). Censo Agropecuário 2017 - Resultados Definitivos. Instituto Brasileiro de Geografia e Estatística. Available onlibne at: https://sidra.ibge.gov.br/ pesquisa/censo-agropecuario/censo-agropecuario-2017 (accessed March 13, 2021).

JBS (2020). Composição Acionária e Societária. JBS. Available online at: https:// jbss.infoinvest.com.br/investidores-esg/governanca-corporativa/composicaoacionaria-e-societaria (accessed March 13, 2021).

Junior, M. A. M., and Goldfarb, Y. (2021). O agro não é tech, o agro não é pop e muito menos tudo. Abra/ FRIEDRICH-EBERT-STIFTUNG. Available online at: https://library.fes.de/pdf-files/bueros/brasilien/18319-20211027.pdf (accessed March 13, 2021).

Kano, L., Tsang, E. W. K., and Yeung, H. W. C. (2020). Global value chains: a review of the multi-disciplinary literature. J. Int. Business Stud. 51, 577-622. doi: 10.1057/s41267-020-00304-2

Koberg, E., and Longoni, A. (2019). A systematic review of sustainable supply chain management in global supply chains. J. Clean. Prod. 207, 1084-98. doi: $10.1016 /$ j.jclepro.2018.10.033

Leite, S. P. (2020). Ruralidades, enfoque territorial e políticas públicas diferenciadas para o desenvolvimento rural brasileiro: uma agenda perdida? Estudos Soc. Agric. 28, 227-254. doi: 10.36920/esa-v28n1-10

LeiteBrasil (2019). 22o Ranking das Maiores Empresas de Laticínios do Brasil (Associação Brasileira dos Produtores de Leite (Leite Brasil) (ed.)). Campo Grande.

Machado, M. (2013). Doação ou investimento? A atuação legislativa dos parlamentares da bancada ruralista e a questão do financiamento de campanhas. Monografia de Final de Curso - Ciência Política. Brasília: UNB.

Magro, T., Santos, M., Juúnior, L., Silva, J., and Oliveira, E. (2019). Produção bovina e desmatamento: Análise da distribuição espacial da atividade pecuária no estado de Rondônia. IGepec 23, 112-126.

MAPA (2019). Plano Agrícola e Pecuário 2019/2020. Brasília: Ministério da Agricultura Pecuária e Abastecimento.

MAPA (2020). Quantidade de Abate Estadual Por Ano/Espécie. Ministério da Agricultura, Pecuária e Abastecimento (MAPA). Available online at: http:// sigsif.agricultura.gov.br/sigsif_cons/!ap_abate_estaduais_cons?p_select= SIMandp_ano=2019andp_id_especie=9 $($ accessed March 13, 2021).

MAPA (2021). Plano Agrícola e Pecuário 2021/2022. Brasília: Ministério da Agricultura Pecuária e Abastecimento.

Marin, A., and Stubrin, L. (2015). Innovation Innovation in Natural Resources: New Opportunities and New Challenges The Case of the Argentinian Seed Industry. Maastricht. Available online at: http://www.merit.unu.edu/publications/wppdf/ 2015/wp2015-015.pdf (accessed March 13, 2021).

Mcfadden, J. R., and Hoppe, R. A. (2017). The Evolving Distribution of Payments From Commodity, Conservation, and Federal Crop Insurance Programs. Washington, DC: U.S. Department of Agriculture, Economic Research Service, 56.

Medina, G. (2018). Agropecuária Brasileira Diante Das Dinâmicas Internacionais, $1 s t$ Edn. Goiânia: Editora UFG.

Medina, G. (2020). Participação Do Capital Brasileiro Na Cadeia Produtiva Do Leite: Estratégia Para Investimentos Em Segmentos Do Agronegócio Nacional. Rev. Estudos Soc. 22, 146-167.

Medina, G. (2021). Economia Do Agronegócio No Brasil: Participação Brasileira Na Cadeia Produtiva Da Soja Entre 2015 e 2020. Novos Cadernos NAEA 24, 231-54. doi: 10.5801/ncn.v24i1.8521

Medina, G., and Santos, A. (2017). Curbing enthusiasm for brazilian agribusiness: the use of actor-specific assessments to transform sustainable development on the ground. Appl. Geogr. 85, 101-112. doi: 10.1016/j.apgeog.2017.06.003

Medina, G. S., and Cruz, J. E. (Orgs). (2021). Estudos em Agronegócio: participação brasileira nas cadeias produtivas - V. 5. Goiania: Goiânia / Kelps, 390. p.

Mendonça, L. M. (2015). “A Crise Permanente Do Agronegócio." In Direiros Humanos No Brasil. Relatório Da Rede Social de Justiça e Direitos Humanos. São Paulo: Outras Expessões, 238. 
Messenberg, D. (2002). A Elite Parlamentar do Pós-Constituinte: Atores e Práticas. São Paulo: Brasiliense.

Meurer, P. A. S., Assis, F. P. S., and Vian, C. E. V. (2015). Análise Da Agroindústria Canavieira Nos Estados Do Centro-Oeste Do Brasil a Partir Da Matriz de Capacidades Tecnológicas. Rev. Econ. Sociol. Rural 53, 159-178. doi: 10.1590/1234-56781806-9479005301009

Moro, N. D. (2014). A constituição de uma elite rural: o caso dos sojicultores em Mato Grosso do Sul (décadas de 1970-1980). Revista NUPEM Campo Mourão 6, 69-90.

Mossenberg, D. (2002). A elite parlamentar do pós-constituinte: atores e práticas. São Paulo: Brasiliense.

Mueller, B., and Mueller, C. (2016). The political economy of the brazilian model of agricultural development: institutions versus sectoral policy. Quart. Rev. Econ. Finance. 69, 12-20. doi: 10.1016/j.qref.2016.07.012

Nassif, A., Bresser-Pereira, L. C., and Feijo, C. (2017). The case for reindustrialisation in developing countries: towards the connection between the macroeconomic regime and the industrial policy in Brazil. Cambridge J. Econ. 42, 355-81. doi: 10.1093/cje/bex028

Nepomuceno, Í., Affonso, H., Fraser, J. A., and Torres, M. (2019). Counterconducts and the green grab: forest peoples' resistance to industrial resource extraction in the Saracá-Taquera National Forest, Brazilian Amazonia. Glob. Environ. Change 56, 124-133. doi: 10.1016/j.gloenvcha.2019.04.004

Paul, J., and Feliciano-Cestero, M. M. (2020). Five decades of research on foreign direct investment by mnes: an overview and research agenda. J. Business Res. 124, 800-812. doi: 10.1016/j.jbusres.2020.04.017

Potter, C., and Tilzey, M. (2007). Agricultural multifunctionality, environmental sustainability and the WTO: resistance or accommodation to the neoliberal project for agriculture? Geoforum 38, 1290-1303. doi: 10.1016/j.geoforum.2007.05.001

Prokopy, L., Floress, K., Arbuckle J. Jr., Church, S., Eanes, F. R., Gao, Y., et al. (2019). Adoption of agricultural conservation practices in the united states: evidence from 35 years of quantitative literature. J. Soil Water Conserv. 74, 520-534. doi: 10.2489/jswc.74.5.520

Ribeiro Neto, C. R. (2018). Formação política do agronegócio (Doctoral Thesis). Programa de Pós-graduação em Antropologia Social. UNICAMP 2018.

Saes, M. M., and Silveira, R. L. F. (2014). Novas Formas de Organização Nas Cadeias Agropecuárias Brasileiras: Tendências Recentes. Estudos Soc. Agric. 22, 386-407.

Salerno, T. (2017). Cargill's corporate growth in times of crises: how agrocommodity traders are increasing profits in the midst of volatility. Agric. Hum. Values 34, 211-222. doi: 10.1007/s10460-016-9681-8

Santos, M., and Glass, V. (2018). Atlas Do Agronegócio: Fatos e Números Sobre as Corporações Que Controlam o Que Comemos. Rio de Janeiro: Fundação Heinrich Böll.

Schneider, S., Cazella, A. A., and Mattei, L. F. (2021). Post scriptum ao artigo "histórico, caracterização e dinâmica recente do Pronaf - Programa
Nacional de Fortalecimento da Agricultura Familiar.” Revista Grifos 30, 42-67. doi: 10.22295/grifos.v30i51.5660

Sindan (2019). Anuário Da Indústria de Produtos Para Saúde Animal. São Paulo: Sindicato Nacional da Indústria de Produtos para Saúde Animal.

Sindirações (2019). Relatório Anual. São Paulo: Sindicato Nacional da Indústria de Alimentação Animal (Sindirações).

Soendergaard, N. (2018). Modern monoculture and periphery processes: a world systems analysis of the Brazilian Soy expansion from 2000-2012. Rev. Econ. Sociol. Rural 56, 69-90. doi: 10.1590/1234-56781806-947905 60105

Thomé, K., Medeiros, J., and Hearn, B. A. (2017). Institutional distance and the performance of foreign subsidiaries in Brazilian host market. Int. J. Emerg. Mark. 12, 279-295. doi: 10.1108/IJoEM-02-20150031

Tilzey, M. (2021). From neoliberalism to national developmentalism? Contested imaginaries of a postneoliberal future for food and farming. J. Agrarian Change 21, 180-201. doi: 10.1111/joac.12379

Wesz Junior, V. J. (2010). Políticas Públicas de Agroindustrialização na Agricultura Familiar: uma análise do Pronaf-Agroindústria. Rev. Econ. Sociol. Rural 48, 567-596. doi: 10.1590/S0103-20032010000400004

Wesz Junior, V. J., and Grisa, C. (2017). “O Estado e a Soja No Brasil: A Atuação Do Crédito Rural de Custeio (1999-2015),” in Questões Agrárias, Agrícolas e Rurais: Conjunturas e Políticas Públicas, ed R. S. Maluf. E-papers.

Xavier, L. F. (2021). Recursos Do Orçamento Público Federal Destinados Ao Meio Rural: Dinâmica Das Contas Brasileiras Entre 2000 e 2017. Rev. Econ. Sociol. Rural 59, 1-20. doi: 10.1590/1806-9479.2021.21 7682

Conflict of Interest: The authors declare that the research was conducted in the absence of any commercial or financial relationships that could be construed as a potential conflict of interest.

Publisher's Note: All claims expressed in this article are solely those of the authors and do not necessarily represent those of their affiliated organizations, or those of the publisher, the editors and the reviewers. Any product that may be evaluated in this article, or claim that may be made by its manufacturer, is not guaranteed or endorsed by the publisher.

Copyright (c) 2022 Corcioli, Medina and Arrais. This is an open-access article distributed under the terms of the Creative Commons Attribution License (CC BY). The use, distribution or reproduction in other forums is permitted, provided the original author(s) and the copyright owner(s) are credited and that the original publication in this journal is cited, in accordance with accepted academic practice. No use, distribution or reproduction is permitted which does not comply with these terms. 